THE RING 31, 1 (2009) DOI 10.2478/v10050-008-0044-8

\title{
BIOMETRICS OF THE DUNLIN (Calidris alpina) MIGRATING IN AUTUMN ALONG THE POLISH BALTIC COAST
}

\author{
Włodzimierz Meissner and Robert Krupa
}

\begin{abstract}
Meissner W., Krupa R. 2009. Biometrics of the Dunlin (Calidris alpina) migrating in autumn along the Polish Baltic coast. Ring 31, 1: 3-13.

The aim of this study is to present the general biometrical characteristics of Dunlins passing the Polish Baltic coast during autumn migration. Data were collected between the first week of July and the end of September in 1991-2002. Comparison of the mean wing lengths of Dunlins from different regions revealed that birds migrating through the Puck Bay had on average shorter wings than those trapped in areas located more south-easterly and clearly longer than those from Mauritania. In adults, seasonal variation of mean bill and wing lengths showed sigmoid pattern with larger birds in July at the beginning of migration and in mid-September. Such pattern is typical for this species, because females, which are larger than males, migrate earlier. Similar pattern of seasonal changes of mean bill and wing lengths might be noted in second-year birds. Juveniles caught in July must have belonged to local population of $C$. a. shinzii, which is smaller than the nominative subspecies. The sample of juvenile birds trapped in the beginning of August probably consisted of individuals from both subspecies, which resulted in the lower mean values of wing and bill lengths. Changes in the size of juveniles from year to year might be caused by differences in food availability on the breeding grounds, e.g. due to weather conditions.
\end{abstract}

W. Meissner, Avian Ecophysiology Unit, Department of Vertebrate Ecology and Zoology, University of Gdańsk, Legionów 9, PL-80-441 Gdańsk, Poland, E-mail: w.meissner@univ.gda.pl; R. Krupa, Department of Zoology, University of Warmia and Mazury in Olsztyn, Oczapowskiego 5, PL-10-975 Olsztyn, Poland, E-mail: krupi.r@gmail.com

Key words: Dunlin, autumn migration, biometrical analysis, Puck Bay

\section{INTRODUCTION}

The Dunlin is the most numerous wader species migrating in autumn along the Baltic coasts (Kube and Struwe 1994, Meissner and Sikora 1995). Geographical variation within its Palaearctic part of breeding range received much attention (Glutz 
von Blotzheim et al. 1975, Greenwood 1984, Tomkovich 1986, Browning 1991, Wennerberg et al. 1999). It is known that at least two subspecies migrate through the Baltic area: $C$. a. shinzii from local breeding population and $C$. a. alpina inhabiting vast area between Scandinavia and North Central Siberia (Glutz von Blotzheim et al. 1975). The eastern border of the Dunlin population migrating through Europe remains poorly known, but there is evidence that some birds may originate from as far east as the Taimyr Peninsula from the breeding area of subspecies $C$. a. centralis (Gromadzka 1985a, 1989; Goede et al. 1990).

Despite thousands of individuals measured in Europe (e.g. Gromadzka 1998, Meissner and Remisiewicz 1998) biometrical data can be found only in a few publications from Sweden (Mascher and Marcström 1976), Germany (OAG Münster 1976, Onnen 1991), France (Fuchs 1973) and Poland (Zając 1980). However, in the majority of them only mean values were given without more comprehensive analyses.

The aim of this study is to present the general biometrical characteristics of Dunlins passing the Polish Baltic coast during autumn migration. Particular emphasis was put on inter- and intraseasonal variability of mean measurements of juvenile, second year and adult birds.

\section{MATERIAL AND METHODS}

Birds were caught mainly in walk-in traps at two ringing sites at the Puck Bay the westernmost part of the Gulf of Gdańsk (Fig. 1) in 1991-2002. More detailed description of the study area was given elsewhere (Meissner and Remisiewicz 1998). The fieldwork started about the first week of July and finished at the end of September, except for 2002, when Dunlins were caught only during two weeks of September. The results of regular counts showed that this period covered the whole migration of

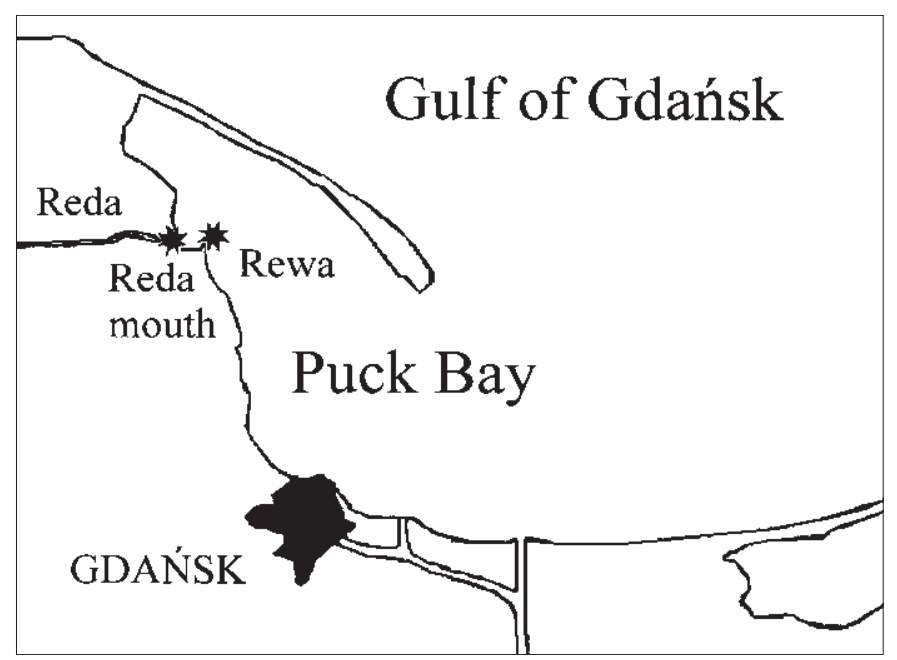

Fig. 1. The study area. Ringing sites are indicated by asterisks. 
adults, while first-year birds were still present quite numerously in the study area in October (Meissner and Sikora 1995).

Each caught birds was aged according to Prater et al. (1977) and Gromadzka (1985b). Three age classes were distinguished: first-year, second-year and adult (older than 2 years) birds. Some late migrating second-year birds which finished moult of inner median coverts into winter plumage might have been included into category "adults". It is impossible to assess the number of such individuals, but probably this had no important influence on obtained results, because on average the second-year birds migrate earlier than adults (Meissner and Strzałkowska 2006). These two age categories were easily distinguishable up to the end of August, while in September the number of Dunlins older that 1 year was very low.

Lengths of bill, head with bill, and tarsus were measured with callipers with accuracy $0.1 \mathrm{~mm}$, while wing and tarsus plus toe lengths were measured with a stopped rule to the nearest $1 \mathrm{~mm}$ (see Meissner 2000 for details). In adult and second-year birds the stage of primary moult was assessed according to Ashmole (1962). To show seasonal variability of mean measurements, the standard five-days period (pentade) scheme was used (Berthold 1973).

Every year the accuracy and repeatability of measurements taken by different ringers were checked as described by Busse (2000). Statistical analysis was done in STATISTICA 8.0 software (StatSoft 2007).

\section{RESULTS}

Among second-year and adult birds there were individuals with old worn and new freshly moulted outer primaries. Nevertheless, differences in the mean wing length between Dunlins with old and new flight feathers were insignificant both in secondyear birds ( $t$-test: $t=0.57, p=0.57$ ) and adults (Cochran-Cox test: $t^{\prime}=0.68, p=0.50$ ). Thus birds with old and new outer primaries were treated jointly in all analyses.

Juveniles, second-years and adults differed significantly in the mean total head, bill, tarsus, tarsus plus toe and wing lengths (ANOVA, see Table 1 for details). However, only in the tarsus and wing lengths significant differences were found among all three age groups (Tuckey post-hoc test at $p<0.05$ ). Juveniles had the shortest while adults the longest tarsus (Table 1). Fot the wing length the highest mean value was found in juveniles, intermediate in adults and the lowest in second-year birds (Table 1). Juveniles had shorter total head but longer tarsus plus toe length than adult and secondyear birds and shorter bill length than second year birds (Table 1). There were no significant differences in means of these measurements between adult and second-year birds.

There was clear bimodality in distributions of wing length, total head length and bill length in adult and second-year birds (Fig. 2 and 3). Lengths of bill and total head of adults are clearly right-skewed (coefficient of skewness 0.20 and 0.16 , respectively), while distributions of other measurements were almost symmetrical (coefficient of skewness $<0.10$ in all cases). In juveniles, wing, bill and total head length distributions showed two peaks (Fig. 2 and 3). 
Table 1

Comparison of mean measurements among juveniles, immatures (second-year birds) and adults of Dunlins caught at the Puck Bay during autumn migration. The mean, standard deviation $(S D)$ and sample size $(N)$ are given. Values in bold differ significantly from other(s) according to the post-hoc Tukey test at $p<0.05$.

\begin{tabular}{|l|c|c|c|c|c|c|c|c|c|c|}
\hline \multirow{2}{*}{ Measurement } & \multicolumn{3}{|c|}{ Juveniles } & \multicolumn{3}{c|}{ Immatures } & \multicolumn{3}{c|}{ Adults } & \multirow{2}{*}{ ANOVA } \\
\cline { 2 - 9 } Total head & $\mathbf{5 6 . 8 9}$ & 2.76 & 9550 & 57.14 & 2.80 & 2178 & 57.06 & 2.67 & 4868 & $\begin{array}{l}F=11.28 \\
p<0.0001\end{array}$ \\
\hline Bill & $\mathbf{3 3 . 1 0}$ & 2.53 & 9540 & $\mathbf{3 3 . 2 9}$ & 2.51 & 2175 & 33.14 & 2.43 & 4876 & $\begin{array}{l}F=5.40 \\
p=0.0045\end{array}$ \\
\hline Tarsus & $\mathbf{2 5 . 1 7}$ & 0.98 & 8194 & $\mathbf{2 5 . 2 5}$ & 0.98 & 1689 & $\mathbf{2 5 . 3 7}$ & 0.97 & 3937 & $\begin{array}{l}F=56.02 \\
p<0.0001\end{array}$ \\
\hline Tarsus+toe & $\mathbf{4 7 . 6 9}$ & 1.77 & 3147 & 47.35 & 1.80 & 657 & 47.44 & 1.77 & 1424 & $\begin{array}{l}F=16.58 \\
p<0.0001\end{array}$ \\
\hline Wing & $\mathbf{1 2 1 . 0}$ & 2.96 & 9563 & $\mathbf{1 1 8 . 8}$ & 3.03 & 1465 & $\mathbf{1 1 9 . 3}$ & 3.10 & 4096 & $\begin{array}{l}F=648.32 \\
p<0.0001\end{array}$ \\
\hline
\end{tabular}

There were significant differences among the means of all measurements in following five-day periods (pentades) (ANOVA: $p<0.05$ in all cases). Data on the bill and wing lengths were chosen to show intraseasonal variation in size of Dunlins passing the study area. Bill length is known to be the best skeletal measurement for sexing the Dunlin (Brennan et al. 1984, Meissner 2005, Meissner and Pilacka 2008), while wing length in wader studies is often used as an indicator of birds' structural size (e.g. Hedenström 2004, Dale et al. 2007, Lehnen and Krementz 2007). In adults, seasonal variation of the mean bill and wing lengths showed sigmoid pattern with larger birds in July at the beginning of migration and in mid-September (Fig. 4). The same pattern was found in second-year birds at least in July and August. Juveniles, which were caught in small numbers early in the season, had much shorter bill and wing lengths (Fig. 4). During the main migrating period (from mid August onwards) the variation in mean measurements in following five-day periods was rather small.
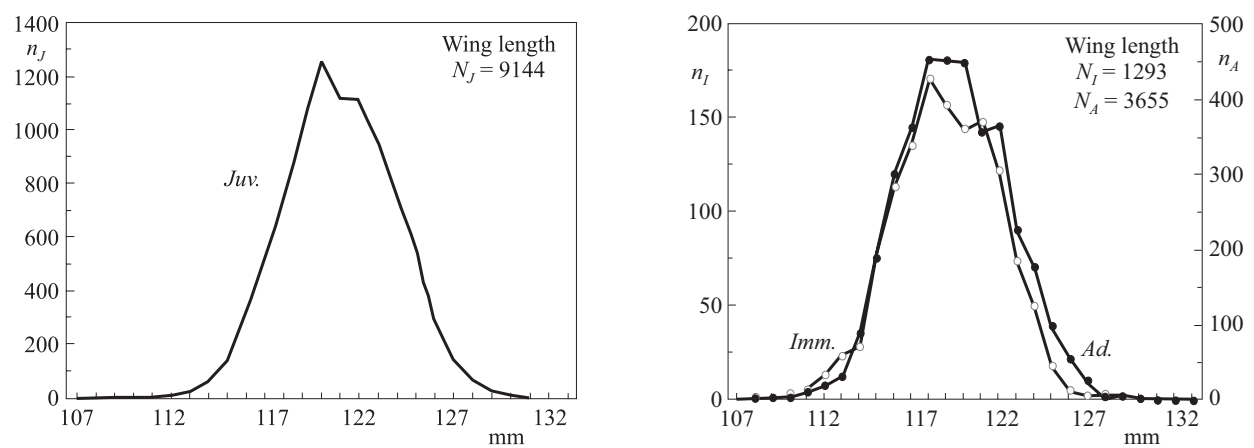

Fig. 2. Distribution of wing lengths of juvenile (Juv.), second year (Imm.) and adult (Ad.) Dunlins caught at the Puck Bay during autumn migration. Data smoothed by moving average. 

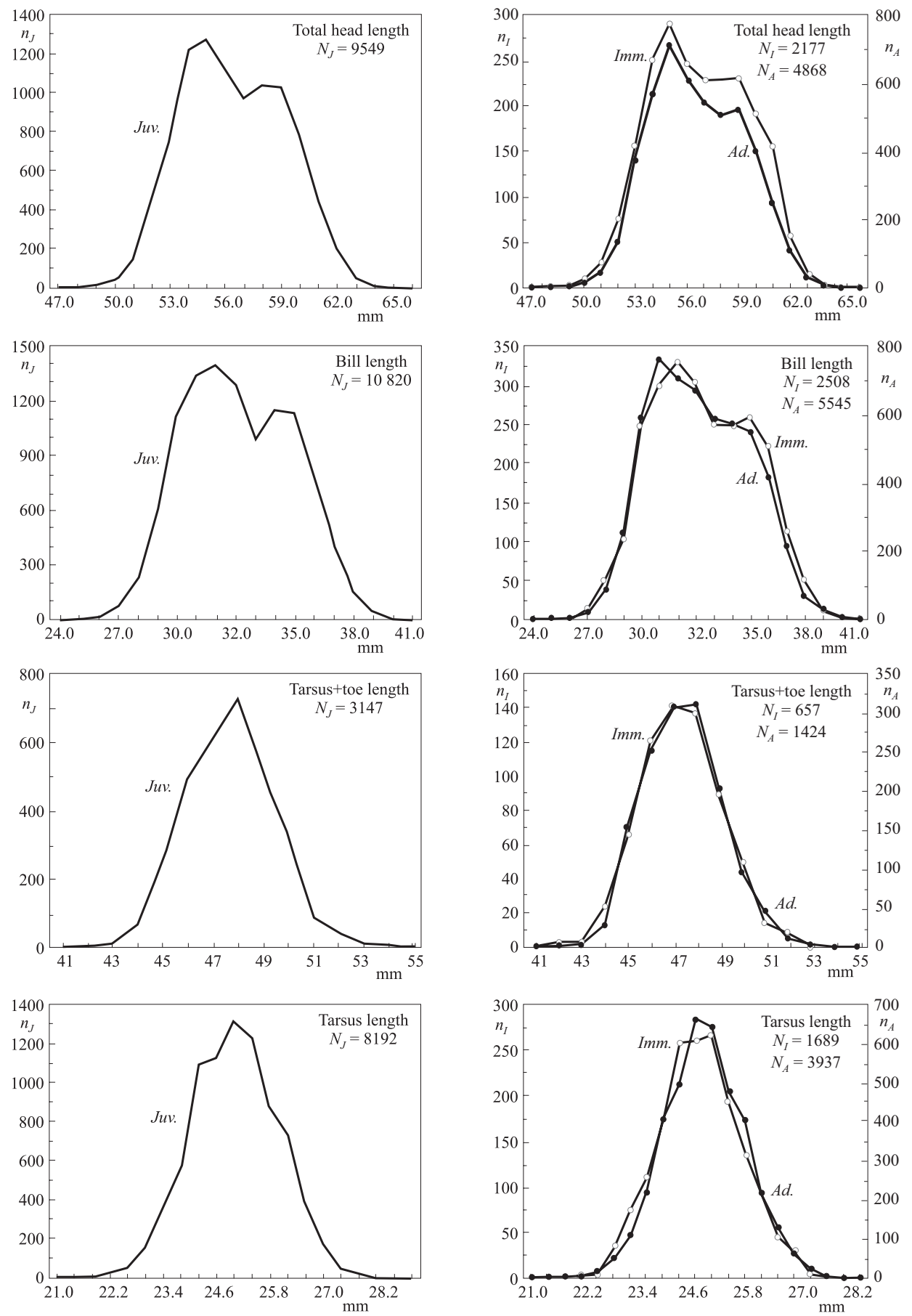

Fig. 3. Distribution of some measurements of juvenile (Juv.), second year (Imm.) and adult (Ad.) Dunlins caught at the Puck Bay during autumn migration. Data smoothed by moving average. 

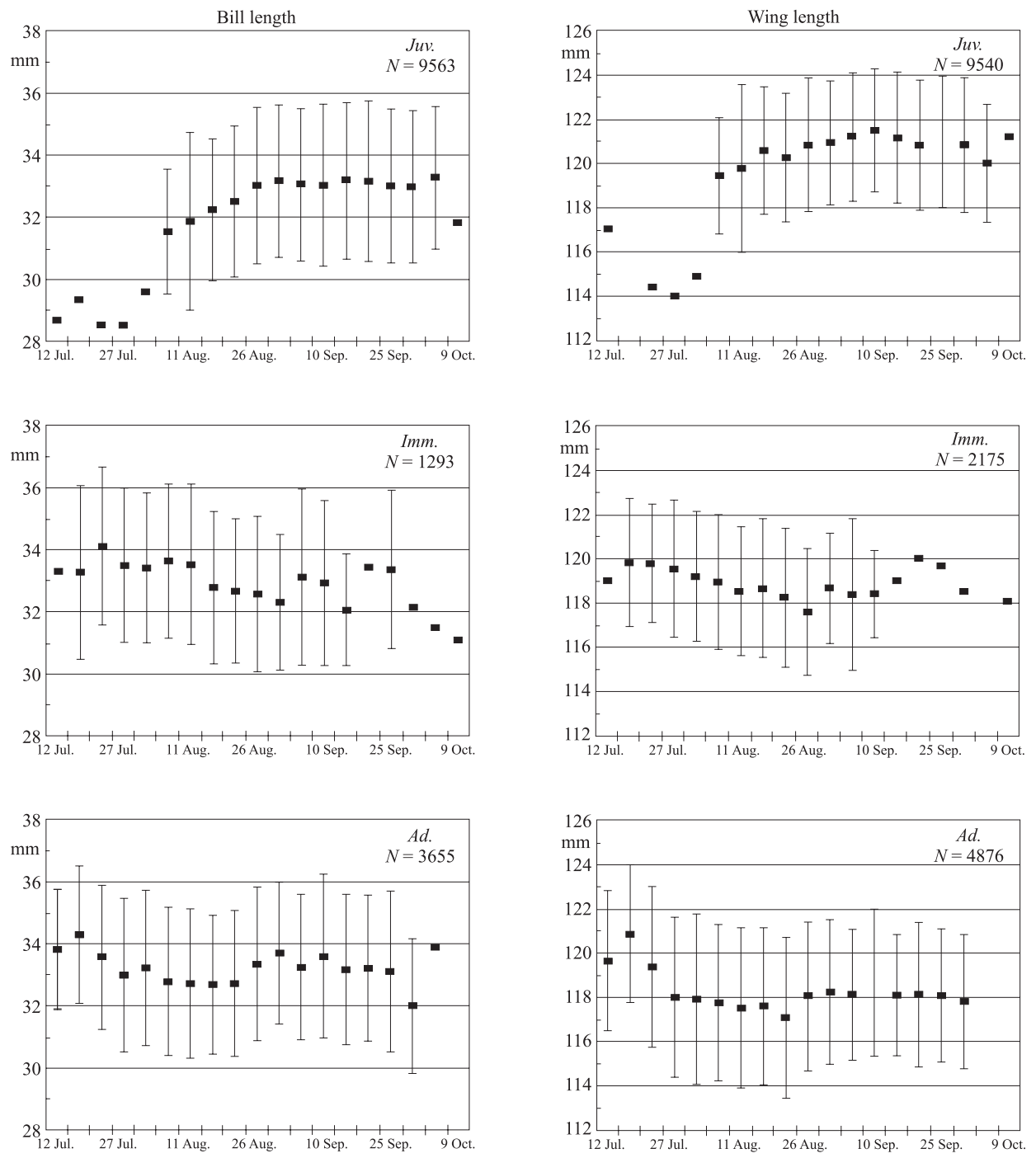

Fig. 4. Changes of mean bill and wing lengths in following five-day periods (pentades) of autumn migration in juvenile (Juv.), second-year (Imm.) and adult (Ad.) Dunlins. Markers - mean values, vertical lines - standard deviations $( \pm S D)$. Total sample sizes are given. For subsample sizes less than 10 only mean values are given.

There is no indication that in this species juvenile males and females migrate separately, whereas in adult and second year birds males migrate on average later than females (Zając 1980). Thus, the yearly mean measurements of adult birds might be biased due to differences in catching effort in different parts of the migration period. That is why the interseasonal variation in mean measurements of Dunlins was analysed only for juvenile birds. There was significant variation among seasons in the means of total head (ANOVA: $F_{11,9538}=29.02, p<0.001$ ), bill (ANOVA: $F_{11,9528}=34.82$, 
$p<0.001$ ), tarsus (ANOVA: $F_{9,8184}=42.88, p<0.001$ ) and wing (ANOVA: $F_{9,9251}=6.43$, $p<0.001)$ lengths in juvenile Dunlins. Interseasonal variability of the total head, bill and tarsus lengths had similar pattern with higher and lower mean values in the same seasons. Thus, there was strong correlation between the yearly means of total head and tarsus lengths $(r=0.84, p=0.004$, Fig. 5) as well as of bill and tarsus lengths $(r=0.75, p=0.02)$. However, there was no relationship between the total head and wing lengths ( $r=0.59, p=0.09$, Fig. 5), nor between bill and wing lengths $(r=0.60, p=0.09)$.
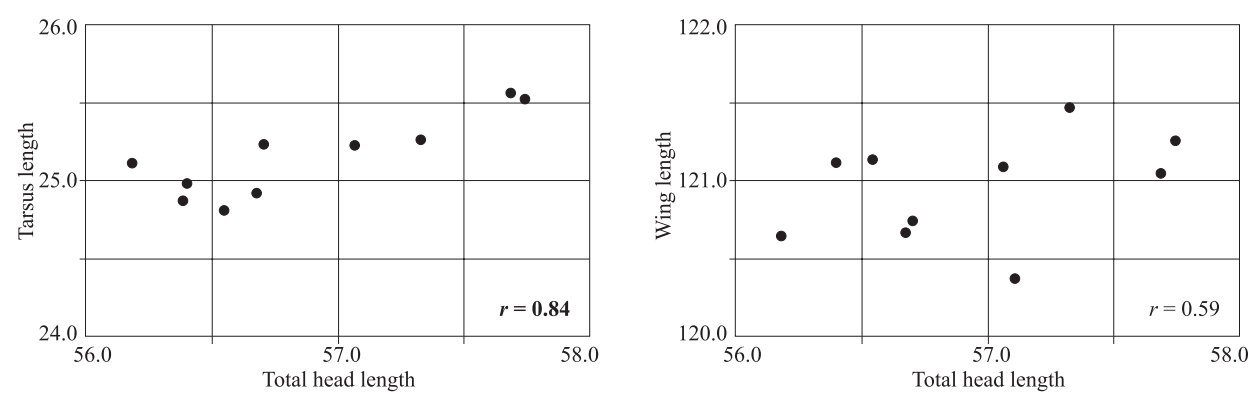

Fig. 5. Correlations between yearly mean measurements of juvenile Dunlins caught at the Puck Bay. Significant correlation coefficient in bold.

\section{DISCUSSION}

Comparison of mean wing lengths of Dunlins from different regions revealed that birds migrating through the Puck Bay had on average shorter wings than those trapped in areas located more south-easterly and clearly longer than those from Mauritania (Fig. 6). Although wintering grounds of different Dunlin populations considerably overlap in the Palaearctic, there is a clear tendency for birds from more western breeding sites to winter in more western areas than birds from eastern part of the range (Greenwood 1984, Wennerberg 2001). It seems that larger birds caught during migration in Greece and Bahrain came from more eastern breeding grounds, which was also supported by results of mtDNA analyses (Wennerberg 2001). It should be noted that in this species the difference in the beginning of egg lying along the eastwest gradient of Arctic Russia reaches three weeks (Holmgren et al. 2001) and eastern populations begin migration after primary moult - later than those breeding more westerly (Glutz von Blotzheim et al. 1975, Gromadzka 1989). Vast majority of adults arriving to the study area in late August and September showed some features, such as colouration of inner primaries and wing coverts or finished moult of all flight feathers, typical for Dunlins inhabiting more eastern parts of the Siberian breeding range (Gromadzka 1989). This suggests that these birds may come from the eastern part of $C$. a. alpina or from the $C$. a. centralis breeding range. Thus, it seems that apart from $C$. $a$. shinzii there are two groups of Dunlins passing southern Baltic in autumn: birds from the western part of $C$. a. alpina breeding range, which migrate 
earlier, and birds breeding further east, arriving later to the study area. Hence, the reason for a remarkable range of wing lengths in adult Dunlins (Fig. 6) is probably the fact that the analysed sample consisted of birds from a vast area, which differed in biometrics.

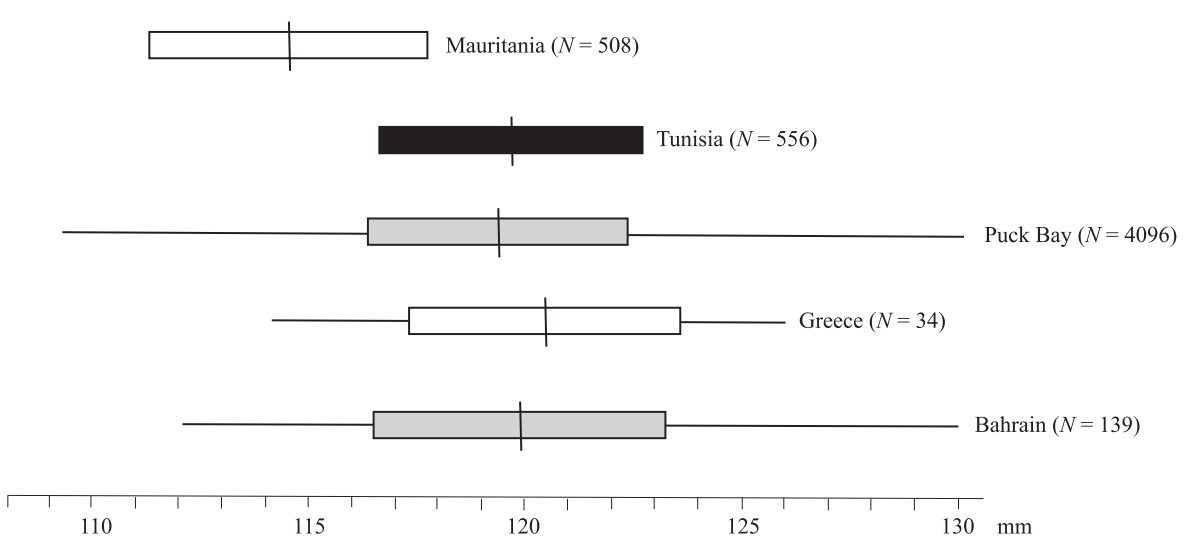

Fig. 6. Comparison of wing lengths of adult Dunlins caught at different sites. Vertical lines - mean values, rectangles - standard deviations $( \pm S D)$, horizontal lines - ranges. Data from autumn and early winter (grey), from winter (black) and spring (white), after Meininger et al. (1987), Wymenga et al. (1990), Hirschfeld et al. (1992), van der Have et al. (1997) and this study.

In adults and second-year birds a not very clear bimodality in bill length, which is the best measurement to separate sexes in Dunlin, may be caused by the presence of birds from different geographical populations in the analysed sample. The studied period covered almost the whole period of adult and second-year birds migration, but only a little more than a half of the total period of juveniles passage (Meissner and Sikora 1995). Thus, probably the sample of juveniles was more homogeneous regarding population structure, because it consisted almost exclusively of the earlier migrants. Similar results were obtained by Onnen (1991) in northern Germany, where only bill and wing lengths of juvenile birds showed bimodal distribution.

The pattern of seasonal changes of the mean bill length in July and August described earlier by Zając (1980) was caused by different migration time of both sexes. Females, which are larger than males, migrate earlier, when majority of males still remain in breeding grounds rearing chicks (Glutz von Blotzheim et al. 1975). Gradual increase of the mean bill length from the third decade of August and decrease in the end of September suggest that in this period adults from other than C. a. shinzii population passed the study area with larger females migrating earlier than males. As it was mentioned earlier, majority of these birds had finished primary moult and had "adult-buff" coverts, which were different from the earlier migrants. Similar pattern of seasonal changes of the mean bill and wing lengths was noted in the second-year birds. However, second-year Dunlins usually migrate somewhat earlier than older birds (Meissner and Strzałkowska 2006). The variation of mean measurements can indicate that a large part of these birds also take part in breeding. Gromadzka (1989) 
claimed that the most of second-year Dunlins caught at the Polish Baltic coast in July and August had well developed incubation patches, implying that they at least started preparing to breed.

Juveniles caught in July must have been originating from local, Baltic population of $C$. a. shinzii, which is smaller than the nominative subspecies. In the first half of August, at the beginning of the main migration period of juvenile birds, their mean measurements were still lower than in the later stage of the passage. The same pattern was found in north-western Germany, where juveniles caught in August had also much shorter bill and wing lengths in comparison with birds from September (OAG Münster 1976). Juvenile birds from C. a. shinzii leave Baltic in the first half of August at the latest (Glutz von Blotzheim et al. 1975), thus the sample of birds trapped in the beginning of August might have consisted of individuals from both subspecies and this resulted in lower mean values of wing and bill lengths.

In Dunlin, females are larger than males. This difference is also well pronounced in juveniles (Meissner 2005). Therefore, the variation in measurements from year to year might result from changes in sex ratio. However, there is no evidence that autumn juvenile sex ratios vary between years or that birds of one sex are more likely to be caught than the other or that there are any between-sex differences in migration phenology. Moreover, the frequency distributions of bill measurements plotted separately for each year are bimodal and quite symmetrical suggesting that there is no skewing of sex ratios. Changes in the size of juveniles from year to year were described in other wader species (Meissner 1997, 2004; Meissner and Górecki 2006) and probably were caused by differences in food availability on the breeding grounds, e.g. due to weather conditions (Pearce-Higgins and Yalden 2002, Schekkerman et al. 2003). Bad weather can reduce insect availability in the Arctic (Hodkinson et al. 1996) and cause a reduction in the size of juveniles, because chicks fed with less food grow more slowly and reach a smaller size (Kersten and Brenninkmeijer 1995).

The bill, total head and tarsus lengths are skeletal measurements, while the value of wing length depends almost exclusively on feathers length. It is known that low food availability during the whole feather growth period may reduce wing length (Pehrsson 1987). Analysing correlations between these parameters (see Fig. 5), it seems that in a given season other factors had an influence on wing growth than on skeletal measurements.

\section{ACKNOWLEDGEMENTS}

We are grateful to all the colleagues from the WRG KULING ringing team, who helped in the fieldwork, especially to Maciej Kozakiewicz, Anna Włodarczak-Komosińska, Magdalena Remisiewicz, Dariusz Górecki, Cezary Wójcik, Norbert Pokorski, Mateusz Ściborski, Piotr Zięcik, Piotr Rydzkowski and Marcin Polak, who collected a lot of data used for this publication. This is the paper of the Waterbird Research Group KULING no 134. 


\section{REFERENCES}

Ashmole N.P. 1962. The Black Noddy Anous tenuirostris on Ascension Island. Part I. General biology. Ibis 103: 235-273.

Berthold P. 1973. Proposals for the standardisation of the presentation of data of animal events, especially migratory data. Auspicium, Suppl.: 49-57.

Brennan L.A., Buchanan J.B., Schick C.T., Herman S.G., Johnson T.M. 1984. Sex determination of Dunlins in winter plumage. J. Field Ornithol. 55: 343-348.

Browning M.R. 1991. Taxonomic comments on the Dunlin, Calidris alpina, from Northern Alaska and Eastern Siberia. Bull. Br. Ornithol. Club 111: 140-145.

Busse P. (Ed). 2000. Bird station manual. SE European Bird Migration Network. Gdańsk Univ. Press, Gdańsk.

Dale J., Dunn P.O., Figuerola J., Lislevand T., Székely T., Whittingham L.A. 2007. Sexual selection explains Rensch's rule of allometry for sexual size dimorphism. Proc. R. Soc. B. 274: 2971-2979.

Fuchs E. 1973. Durchzug und Überwinterung des Alpenstrandläufers Calidris alpina in der Camargue. Ornithol. Beob. 70: 113-134.

Glutz von Blotzheim U.N., Bauer K.M., Bezzel E. 1975. Handbuch der Vögel Mitteleuropas. vol. 7. Charadriiformes. Akademische Verlag, Wiesbaden.

Goede A.A., Nieboer E., Zegers P.M. 1990. Body mass increase, migration pattern and breeding grounds of Dunlins, Calidris alpina, staging in the Dutch Wadden Sea in spring. Ardea 78: 135-144.

Greenwood J.G. 1984. Migration of Dunlin Calidris alpina: a worldwide overview. Ring. \& Migr. 5: 35-39.

Greenwood J.G. 1986. Geographical Variation and Taxonomy of the Dunlin Calidris alpina. Bull. Brit. Orn. Club. 106: 43-56.

Gromadzka J. 1985a. [Dunlin - Calidris alpina (L.).] In: Viksne J.A., Michelson H.A. (Eds). [Migration of birds of Eastern Europe and Northern Asia.] Nauka. Moscow. (In Russian).

Gromadzka J. 1985b. Further observations on the wing plumage in Dunlins. Wader Study Group Bull. 44: 32-33.

Gromadzka J. 1998. Wader ringing at the Vistula mouth (Baltic coast, Poland) - a summary of the long-term studies. Ring 20, 1-2: 5-20.

Gromadzka J. 1989. Breeding and wintering areas of Dunlin migrating through southern Baltic. Ornis Scand. 20. 1-2: 132-144.

Hedenström A. 2004. Migration and morphometrics of Temminck's Stint Calidris temminckii at Ottenby, southern Sweden. Ring. \& Migr. 22: 51-58.

Hirschfeld E., Mohamed S.A., Stawarczyk T. 1992. Bahrain shorebird study. WIWO report 42, Zeist.

Hodkinson I.D., Coulson S.J., Webb N.R., Block W., Strathdee A.T., Bale J S., Worland M.R. 1996. Temperature and the biomass of flying midges (Diptera: Chironomidae) in the high Arctic. Oikos 75: 241-284.

Holmgren N.M.A., Jönsson P.E. Wennerberg L. 2001. Geographical variation in the timing of breeding and moult in dunlin Calidris alpina on the Palearctic tundra. Polar Biol. 24: 369-377.

Kersten M., Brenninkmeijer A. 1995. Growth, fledging success and post-fledging survival of juvenile Oystercatchers Haematopus ostralegus. Ibis 137: 336-404.

Kube J., Struwe B. 1994. Die Ergebnisse der Limikolenzählungen an der südwestlichen Ostseeküste 1991. Corax 15, 2: 4-56.

Lehnen S.E., Krementz D.G. 2007. The influence of body condition on the stopover ecology of Least Sandpipers in the Lower Mississippi Alluvial Valley during fall migration. Avian Conserv. Ecol. 2, 2: 9. 
Mascher J.W., Marcström V. 1976. Measures, weights and lipid levels in migrating Dunlins Calidris alpina L. at Ottenby Bird Observatory, South Sweden. Ornis Scand. 7: 49-59.

Meininger P.L., Spiekman H., Van Westrienen R. 1987. Measurements and plumage of shorebirds captured in north-east Greece, spring 1987. In: Meininger P.L. (Ed). Birds of the Wetlands in North-east Greece, Spring 1987. WIWO report 20, Zeist.

Meissner W. 1997. Autumn migration of Wood Sandpiper (Tringa glareola) in the region of the Gulf of Gdańsk. Ring 19, 1-2: 75-91.

Meissner W. 2000. The wader station. In: Busse P. (Ed). Bird station manual. SE European Bird Migration Network. Gdańsk Univ. Press. Gdańsk.

Meissner W. 2004. Variability in the size of juvenile Red Knots Calidris canutus canutus. Wader Study Group Bull. 103: 71-74.

Meissner W. 2005. Sex determination of juvenile Dunlins migrating through the Polish Baltic region. J. Field Ornithol. 76, 4: 368-372.

Meissner W., Górecki D. 2006. Biometrics and body mass variation of Curlew Sandpiper Calidris ferruginea caught on the Puck Bay coast, Poland, during southward migration. International Wader Studies 19: 125-129.

Meissner W., Pilacka L. 2008. Sex identification of adult Dunlins Calidris alpina alpina migrating in autumn through Baltic region. Ornis Fenn. 85, 4: 135-138.

Meissner W., Remisiewicz M. 1998. Wader studies of the Waterbird Research Group KULING in 1983-1998. Ring 20, 1-2: 31-33.

Meissner W., Sikora A. 1995. Spring and autumn migration of waders (Charadrii) on the Hel Peninsula. Not. Orn. 36, 3-4: 205-239.

Meissner W., Strzałkowska M. 2006. Autumn migration of the Dunlin (Calidris alpina) at the Reda Mouth (southern Baltic). Ring 28, 1: 33-43.

OAG Münster 1976. Zur Biometrie des Alpenstrandläufers (Calidris alpina) in den Rieselfeldern Münster. Vogelwarte 28: 278-293.

Onnen J. 1991. Zugphänologie, Biometrie und Gewicht des Alpenstrandläufers (Calidris alpina) im nordwestlichen Niedersachsen. Vogelwarte 36: 132-145.

Pearce-Higgins J.W., Yalden D.W. 2002. Variation in the growth and survival of Golden Plover Pluvialis apricaria chicks. Ibis 144: 200-209.

Pehrsson O. 1987. Effects of body condition on molting in Mallards. Condor 89, 2: 329-339.

Prater A.J., Marchant J.H., Vuorinen J. 1977. Guide to the identification and ageing of Holarctic waders. BTO, Tring.

Schekkerman H., Tulp I., Piersma T., Visser G.H. 2003. Mechanisms promoting higher growth rate in arctic than in temperate shorebirds. Oecologia 134: 332-342.

StatSoft Inc. 2007. STATISTICA (data analysis software system). version 8.0. www.statsoft.com.

Tomkovich P.S. 1986. Geographical variability of the Dunlin in the Far East. Biol. Mosk. o-va. ispit. prir. otd. biol. 91: 3-15.

van der Have T.M., Bacetti N., Chernichko I.I., Gromadzka J. 1997. Origin and sex ratio of dunlins wintering in the Gulf of Gabčs, Tunisia. In: Van Der Have T.M., Bacetti N., Keijl G.O., Zenatello M. (Eds). Waterbirds in Kneiss, Tunisia, February 1994. WIWO report 54, Zeist.

Wennerberg L. 2001. Breeding origin and migration pattern of dunlin (Calidris alpina) revealed by mitochondrial DNA analysis. Mol. Ecol. 10: 1111-1120.

Wennerberg L., Holmgren N.M.A., Jönsson P.-E., Von Schantz T. 1999. Genetic and morphological variation in Dunlin Calidris alpina breeding in the Palearctic tundra. Ibis 141: 391-398.

Wymenga E., Engelmoer M., Smit C.J., Van Spanje C.J., Van Spanje T.M. 1990. Geographical breeding origin and migration of shorebirds wintering in West Africa. Ardea 78: 83-112.

Zając R. 1980. Different autumn migration of sexes in the Dunlin Calidris a. alpina as determined by means of normal probablility paper. Acta orn. 17: 107-118. 